\title{
PENGARUH PEMBERIAN HEALTH EDUCATION TENTANG PENCEGAHANINFEKSI NOSOKOMIAL TERHADAP PENGETAHUAN KELUARGA PASIENDI RUANG ALAMANDA RSUD NGANJUK
}

\author{
Nur Aini Fatimah', Yusmiati Ningsih ${ }^{2}$, Puji Astutik', Agus Khoirul Fuadi ${ }^{1}$ \\ ${ }^{1}$ Dosen Program Studi Pendidikan Ners Stikes Satria Bhakti Nganjuk \\ ${ }^{2}$ Mahasiswa Program Studi Pendidikan Ners Stikes Satria Bhakti Nganjuk
}

Email: yusmiatiningsih1@gmail.com

\begin{abstract}
Introduction: The lack of knowledge of patient families waiting in the treatment room on prevention of nosocomial infections causes increasing the risk of infection. Hospitals need to provide health education to improve patient families' knowledge. The purpose of this study was to determine the effect of giving health education about prevention of nosocomial infection to patient families' knowledge in Alamanda Room of RSUD Nganjuk.Methods:The design of this research is pre experiment with Pre-Post Test Design approach. The population in this study is the entire family of patients in the Alamanda Room Nganjuk Hospital during $27^{\text {th }}$ November until $7^{\text {th }}$ Desember 2017 . The sample was taken by accidental sampling technique and obtained by 30 respondents. Independent variables in the study are health education and the dependent variable is the patient families' knowledge about prevention of nosocomial infection. Data were collected by questionnaire and then analyzed data with Wilcoxon test with $\alpha=0,05$. Results: The results showed that the knowledge of respondents prior to the provision of health education on the prevention of nosocomial infection, most of which is good, as many as 21 respondents $(70 \%)$. Knowledge of respondents after giving health education about prevention of nosocomial infection, mostly good, that is 25 respondents $(83 \%)$. Wilcoxon test produces $p$-value $=0,020(p$-value $\leq \alpha)$ so that hypothesis (Ha) is accepted.Conslusions:There is influence of giving health education about prevention of nosokomial infection to patient families' knowledge in Ruang Alamanda Nganjuk Hospital. The provision of health education on the prevention of nosocomial infections has proven to be very important for patient families who are waiting in the hospital. Increased knowledge can affect the attitude and actions of the patient families, so that cases of nosocomial infections can be minimized.
\end{abstract}

Keywords:Health Education, Nosocomial Infection, Knowledge, Patient Families.

\section{PENDAHULUAN}

Rumah sakit selain merupakan unit pelayanan kesehatan juga tempat bertemunya sejumlah orang secara serempak yang berinteraksi dengan pasien, termasuk keluarga pasien yang menjenguk maupun menunggu pasien (Fajriyah, 2015).Semakin banyak jumlah pasien dalam rumah sakit, semakin banyak pula keluarga pasien yang menunggu di rumah sakit dan dapat menyebabkan risiko terjadinya infeksi nosokomial (Darmadi 2008). Kurangnya pengetahuan keluarga pasien yang menunggu di ruang perawatan tentang 
pencegahaninfeksi nosokomial menyebabkan pasien mengabaikan prinsipprinsip aseptik, sehingga risiko infeksi semakin tinggi (Anis, 2013). Berdasarkan studi pendahuluan pada Bulan Juni 2017 di Ruang Alamanda RSUD Nganjuk, ditemukan keluarga pasien di ruang perawatan yang batuk tanpa menutup mulutnya (15 orang), membawa serta anak di bawah umur ( $\leq 10$ tahun) (10 orang), dan keluarga pasien saat menyentuh makanan tanpa mencuci tangan terlebih dahulu (10 orang), sehingga dapat meningkatkan risiko penularan infeksi nosokomial di Ruang Alamanda RSUD Nganjuk.

Infeksi nosokomial atau hospital acquired infection merupakan salah satu penyebab meningkatnya angka kematian di rumah sakit, sehingga dapat menjadi masalah kesehatan baru baik di negara berkembang maupun di negara maju (Darmadi, 2008). Survei WHO pada tahun 2005 meliputi 55 rumah sakit yang tersebar di beberapa negara maju dan berkembang di seluruh dunia menunjukkan rata-rata 8,7\% pasien rumah sakit mengalami infeksi nosokomial. Infeksi ini menyebabkan 1,4 juta kematian setiap hari (WHO, 2005). Di Indonesia, penelitian yang dilakukan Marwoto (2007), menunjukkan bahwa kejadian infeksi nosokomial di lima rumah sakit pendidikan yaitu di RSUP Dr. Sardjito sebesar 7,94\%, RSUD Dr. Soetomo sebesar 14,6\%, RS Bekasi sebesar 5,06\%, RS Hasan
Sadikin Bandung sebesar 4,60\%, dan RSCM Jakarta sebesar 4,60\%. Di Jawa Timur, dilaporkan insiden infeksi nosokomial terus mengalami peningkatan, yaitu sebanyak 306 pada tahun 2011, 400 pada tahun 2012, dan 526 pada tahun 2013. Di RSUD Nganjuk pada tahun 2015 ada pasien anak usia 2 tahun yang terinfeksi diare setelah ikut menjaga kakeknya di rumah sakit yang terdiagnosa diare. Pada tahun 2017 terjadi 1 kasus pasien post SC pre eklamsi berat yang mengalami ISK di Ruang ICU karena dikategorikan sebagai pasien immunocompromise (PPI RSUD Nganjuk, 2017).

Sasaran potensial dari infeksi nosokomial tidak hanya pasien itu sendiri, namun juga para petugas kesehatan dan keluarga pasien yang berkunjung atau menunggu pasien di rumah sakit (Zulkarnain, 2009).Peningkatan risiko infeksi dapat disebabkan karena kurangnya pengetahuan tentang pencegahan infeksi nosokomial. Pengetahuan tersebut mencakup pencegahan tentang teknik-teknik aseptik dasar seperti: mencuci tangan dengan air bersih maupun cairan antiseptik, menggunakan alas kaki, membuang sampah medis pada tempatnya, menggunakan alat pelindung diri dan sebagainya (Anis, 2013). Jika prinsip-prinsip aseptik tersebut diabaikan, maka keluarga pasien rawan terpapar infeksi nosokomial yang dapat berdampak serius, karena penularan 
mikroorganisme jenis ini umumnya sudah resisten antibiotik.Kerugian yang ditimbulkan akibat infeksi ini adalah lamanya rawat inap (length of stay) yang lebih panjang dan membutuhkan biaya lebih besar serta bertambahnya pasien baru yang awalnya sehat kemudian menjadi sakit setelah mengalami infeksi di rumah sakit.Infeksi nosokomial juga menjadi penyebab meningkatnya kematian pada pasien di rumah sakit (Edhie, 2010).

Pengetahuan keluarga pasien tentang pencegahan infeksi nosokomial sejak dini dapat memutus rantai infeksi. Karena itu, rumah sakit perlu bersikap aktif dalam memberikan pendidikan kesehatan (health education) kepada keluarga pasien tentang pencegahan infeksi nosokomial, khususnya tentang kebersihan tangan dan kewaspadaan isolasi diri terhadap pasien yang dikunjungi maupun pasien lain di rumah sakit (Kemenkes RI, 2011). Di Ruang Alamanda RSUD Nganjuk saat ini telah diupayakan health education dengan memasang posterposter pencegahan infeksi nosokomial.Selain itu perawat secara rutin berkunjung ke kamar perawatan pasien untuk memberikan penyuluhan tentang teknik aseptik pada keluarga pasien untuk meningkatkan pengetahuan mereka tentang pencegahan infeksi nosokomial.Tujuan yang ingin dicapai adalah peningkatan pengetahuan dan perubahan perilaku keluarga pasien agar lebih memperhatikan prinsip-prinsip aseptik ketika berada di rumah sakit.

\section{METODE PENELITIAN}

Penelitian ini merupakan jenis penelitian pre eksperimen dengan pendekatan pre-post test design.Penelitian akan dilaksanakan padatanggal 27 November - 7 Desember 2017 berlokasi di Ruang Alamanda RSUD Nganjuk.Populasi dalam penelitian ini adalah seluruh keluarga pasien di Ruang Alamanda RSUD Nganjuk selama Bulan November dan Desember 2017.Sampel penelitian ini diambil dengan teknik accidental samplingdan diperoleh besar sampel sebanyak 30 orang responden.

Variabel independen dalam penelitian adalah pendidikan kesehatan (health education) dan variabel dependen adalah pengetahuan keluarga pasien tentang pencegahan infeksi nosokomial.Pengumpulan data pengetahuan keluarga pasien dalam penelitian ini menggunakan instrumen kuesioner yang dibagikan sebelum (pre-test) diberikan pendidikan kesehatan. Selanjutnya peneliti memberikan pendidikan kesehatan selama 10 menit. Kemudian kuesioner dibagikan kembali sesudah (post-test) diberikan pendidikan kesehatan.

Scoring pengetahuan keluarga pasien berdasarkan pedoman kriteria:

Jawaban benar : skor 1

Jawaban salah $\quad:$ skor 0 
Kemudian dari masing-masing jawaban dijumlahkan dan dibandingkan dengan jawaban diharapkan lalu dikalikan $100 \%$, dengan rumus sebagai berikut (Arikunto, 2010):

$$
P=\frac{S P}{S M} \times 100 \%
$$

Keterangan:

P : Persentase

SP : Skor yang diperoleh

SM : Skor maksimum

Hasil persentase diinterpretasikan dengan menggunakan skala ordinal (Nursalam, 2016):

Pengetahuan Baik $=76 \%-100 \%$ : skor 3

Pengetahuan Cukup $=56 \%-75 \%$ : skor 2

Pengetahuan Kurang $=\leq 55 \%$ : skor 1

Analisa data statistik dilakukan dengan uji Wilcoxon dengan $\alpha=$ 0,05.Adapun pedoman untuk pengujian hipotesis adalah:

1. Bila $\rho$-value $\leq \alpha(0,05)$, maka Ha diterima atau Ho ditolak, yang artinya ada pengaruh pemberian health education tentang pencegahan infeksi nosokomial terhadap pengetahuan keluarga pasien di Ruang Alamanda RSUD Nganjuk.

2. Bila $\rho$-value $>\alpha(0,05)$, maka Ha ditolak Ho diterima, yang artinya tidak ada pengaruh pemberian health education tentang pencegahan infeksi nosokomial terhadap pengetahuan keluarga pasien di Ruang Alamanda RSUD Nganjuk.

\section{HASIL PENELITIAN}

Tabel 1. Hasil Penelitian Pengetahuan tentang Infeksi Nosokomial.

\begin{tabular}{clcc}
\hline Variabel & Kategori & $f$ & $\%$ \\
\hline $\begin{array}{c}\text { Pengetahuan } \\
\text { tentang Infeksi } \\
\text { Nosokomial } \\
\text { (pre test) }\end{array}$ & Baik & 21 & 70,0 \\
Jumlah & Kurang & 3 & 10,0 \\
\hline $\begin{array}{c}\text { Pengetahuan } \\
\text { tentang Infeksi } \\
\text { Nosokomial } \\
\text { (post test) }\end{array}$ & Baik & 25 & 83,0 \\
\hline Jumlah & & 5 & 17 \\
\hline
\end{tabular}

Hasil penelitian menunjukkan bahwa dari 30 responden sebelum pemberian health education tentang pencegahan infeksi nosokomial, sebagian besar memiliki pengetahuan yang baik, yaitu sebanyak 21 responden (70\%).Diketahui pula dari 30 responden sesudah pemberian health education tentang pencegahan infeksi nosokomial, hampir seluruhnya memiliki pengetahuan yang baik, yaitu sebanyak 25 responden $(83 \%)$.

Tabel 2. Tabulasi Silang Pengetahuan tentang Infeksi Nosokomial antara Sebelum (Pre) dengan Sesudah (Post) Pemberian Health Education.

\begin{tabular}{lcccc}
\hline \multirow{2}{*}{ Pengetahuan } & \multicolumn{2}{c}{ Sebelum (Pre) } & \multicolumn{2}{c}{ Sesudah (Post) } \\
\cline { 2 - 5 } & $F$ & $\%$ & $f$ & $\%$ \\
\hline Baik & 21 & 70,0 & 25 & 83,0
\end{tabular}




\begin{tabular}{lcccc} 
Cukup & 6 & 20,0 & 5 & 17,0 \\
Kurang & 3 & 10,0 & 0 & 0,0 \\
\hline \multicolumn{1}{c}{ Total } & 30 & 100,0 & 30 & 100,0 \\
\hline$p$-value $=0,020$ & $\alpha=0,05$ & & \\
\hline
\end{tabular}

Tabulasi silang menunjukkan bahwa jumlah responden yang memiliki pengetahuan baik mengalami peningkatan dari 21 responden $(70 \%)$ pada saat sebelum (pre) pemberian health education menjadi 25 responden pada saat sesudah (post) pemberian health education.

Hasil uji Wilcoxondengan $\alpha=0,05$ menunjukkan bahwap-value $=0,020 \quad(p$ value $\leq \alpha$ ) sehingga Ha diterima artinya ada pengaruh pemberian health education tentang pencegahan infeksi nosokomial terhadap pengetahuan keluarga pasien di Ruang Alamanda RSUD Nganjuk.

\section{PEMBAHASAN}

\section{Pengetahuan Keluarga Pasien}

\section{Sebelum Pemberian Health Education}

Hasil penelitian ini menunjukkan bahwadari 30 responden sebelum pemberian health education tentang pencegahan infeksi nosokomial, sebagian besar memiliki pengetahuan yang baik, yaitu sebanyak 21 responden (70\%). Hal ini dapat dihubungkan dengan umur keluarga pasien dimana hampir setengahnya memiliki umur 31-40 tahun, yaitu sebanyak 13 responden $(43,3 \%)$ dengan $p$-value $=0,000$ dan dapat dihubungkan dengan tingkat pendidikan keluarga pasien dimana sebagian besar responden memiliki tingkat pendidikan SMA, yaitu sebanyak 17 responden (56,7\%)dengan $p$-value $=0,000$.

$$
\text { Menurut Notoatmodjo }
$$
pengetahuan dapat dipengaruhi oleh umur seseorang. Semakin cukup umur, tingkat kematangan seseorang akan lebih matang dalam berpikir dan bekerja. Dari segi kepercayaan masyarakat, seseorang yang lebih dewasa akan lebih dipercaya dari orang yang belum cukup tinggi kematangannya. Seiring bertambahnya usia seseorang, maka pengalaman hidupnya turut bertambah. Semakin banyak pengalaman seseorang tentang suatu hal maka semakin bertambah pengetahuan akan hal tersebut. Notoatmodjo (2011) juga menjelaskan bahwa pendidikan memiliki peranan yang besar dalam membentuk pengetahuan seseorang tentang kesehatan. Semakin tinggi tingkat pendidikan seseorang, maka semakin mudah orang tersebut dalam menerima informasi, sehingga semakin banyak pula pengetahuan yang dimiliki.

Hampir setengah responden keluarga pasien yang berumur 31-40 tahun tergolong dalam umur yang sudah cukup matang, sehingga dapat berpikir secara rasional, mampu mencerna informasi dengan baik dan memiliki banyak pengalaman hidup, khususnya terkait dengan pencegahan infeksi nosokomial. Hal ini didukung pula dengan tingkat pendidikan sebagian besar 
responden keluarga pasien setingkat SMA, sehingga dapat digolongkan sudah berpendidikan cukup untuk mampu mengembangkan logika berpikir dan memperoleh akses pengetahuan.Karena itu, sebagian besar responden sudah memiliki pengetahuan yang baik tentang pencegahan infeksi nosokomial, walaupun belum diberi health education. Pengetahuan tersebut kemungkinan besar sudah diperoleh dari sumber-sumber informasi yang lain sesuai kematangan umur dan tingkat pendidikan yang memadai.

\section{Pengetahuan Keluarga Pasien Sesudah Pemberian Health Educatio}

Hasil penelitian ini menunjukkan bahwadari 30 responden sesudah pemberian health education tentang pencegahan infeksi nosokomial, hampir seluruhnya memiliki pengetahuan yang baik, yaitu sebanyak 25 responden (83\%). Hal ini dapat dihubungkan dengan tingkat pendidikan keluarga pasien dimana sebagian besar responden memiliki tingkat pendidikan SMA, yaitu sebanyak 17 responden (56,7\%)dengan $p$-value $=0,000$ dan dapat juga dihubungkan dengan jenis pekerjaan keluarga pasien dimana sebagian besar tidak bekerja atau berperan sebagai ibu rumah tangga, yaitu sebanyak 9 responden (30\%)dengan $p$-value $=0,017$.

Menurut Mubarak (2007), pendidikan merupakan dasar pengetahuan intelektual yang dimiliki seseorang, semakin tinggi pendidikan akan semakin besar kemampuan untuk menyerap dan menerima informasi. Selain itu pendidikan merupakan salah satu faktor yang melatarbelakangi tindakan yang dilakukan dan selanjutnya akan mempengaruhi perilaku seseorang. Mubarak (2007) juga menjelaskan bahwa status pekerjaan ibu rumah tangga umumnya lebih sering di rumah, sehingga memungkinkan mempunyai pengetahuan terbatas, lingkungan rumah jika tidak ditunjang dengan mencari informasi tambahan melalui media informasi yang dimilikinya seperti radio dan televisi atau membaca buku-buku tentang kesehatan. Namun ibu rumah tangga sebenarnya mempunyai waktu lebih banyak untuk menambah wawasan sehingga meningkatkan pengetahuan.

Peneliti berpendapat bahwa sebagian besar responden keluarga pasien memiliki tingkat pendidikan yang cukup memadai, yaitu setingkat SMA.Hal ini membuat responden mampu menyerap informasi dengan cepat yang diberikan melalui health education tentang pencegahan infeksi nosokomial.Hal ini didukung pula dengan status pekerjaan responden yaitu tidak bekerja atau berperan sebagai ibu rumah tangga, sehingga memiliki banyak waktu untuk belajar dan menyerap informasi dari berbagai sumber.Karena itu, ketika responden diberi health education tentang pencegahan infeksi nosokomial, mereka 
dapat dengan mudah dan terbuka untuk menerima informasi yang diberikan oleh petugas kesehatan.Hal ini diwujudkan melalui fakta bahwa hampir seluruh responden keluarga pasien memiliki pengetahuan yang baik.

\section{Pengaruh Health Education terhadap Pengetahuan Keluarga Pasien}

Hasil penelitian ini menunjukkan bahwajumlah responden yang memiliki pengetahuan baik mengalami peningkatan dari 21 responden $(70 \%)$ pada saat sebelum (pre) pemberian health education menjadi 25 responden pada saat sesudah (post) pemberian health education. Hasil uji Wilcoxonmenunjukkan bahwap-value= $0,020$ (p-value $\leq \alpha \quad 0,05)$ sehingga $\mathrm{Ha}$ diterima yang berarti bahwa ada pengaruh pemberian health education tentang pencegahan infeksi nosokomial terhadap pengetahuan keluarga pasien di Ruang Alamanda RSUD Nganjuk.

Menurut Nugrohoi (2014), sumber informasi merupakan faktor penting dalam proses pembentukan pengetahuan tentang kesehatan, karena itu informasi yang berasal dari sumber-sumber yang dapat dipertanggungjwabkan, khususnya yang berasal dari tenaga kesehatan, sangat dibutuhkan oleh masyarakat.Notoatmodjo (2011) menyatakan bahwa salah satu faktor eksternal yang mempengaruhi pengetahuan seseorang adalah informasi.Informasi adalah keseluruhan makna dapat diartikan sebagai pemberitahuan seseorang adanya informasi baru bagi terbentuknya sikap terhadap hal tersebut pesan-pesan sugestif dibawa oleh informasi tersebut pendekatan ini biasanya menggunakan media massa. Sedangkan Mubarak dan Chayatin (2009) menyatakan bahwa melalui pendidikan kesehatan (health education) diharapkan terjadi peningkatan pengetahuan dan perubahan perilaku dalam diri individu, atau kelompok masyarakat sendiri.

Peneliti berpendapat bahwa pemberian health educationtentang pencegahan infeksi nosokomial telah berhasil meningkatkan pengetahuan keluarga pasien di Ruang Alamanda RSUD Nganjuk.Melalui health educationtersebut, keluarga pasien memperoleh informasiinformasi penting tentang pengertian infeksi nosokomial, penyebab, carapenularan, faktor risiko, dan upaya pencegahan infeksi nosokomial. Sebelum diberi health education, memang ternyata sebagian besar responden sudah memiliki pengetahuan yang baik, namun sesudah diberi health education, pengetahuan tersebut meningkat.Seluruh responden yang awalnya memiliki pengetahuan rendah meningkat menjadi cukup dan baik, kemudian sebagian responden yang awalnya memiliki pengetahuan cukup meningkat menjadi baik.Karena itu, kegiatan pemberian health education tentang pencegahan infeksi 
nosokomial terbukti sangat penting untuk dilaksanakan bagi keluarga pasien yang menunggu di ruah sakit, sehingga kasus infeksi nosokomial dapat ditekan seminimal mungkin.

\section{KESIMPULAN}

Berdasarkan hasil penelitian dan pembahasan, maka dapat disimpulkan:

1. Pengetahuan responden sebelum pemberian health education tentang pencegahan infeksi nosokomial, sebagian besar adalah baik, yaitu sebanyak 21 responden $(70 \%)$.

2. Pengetahuan responden sesudah pemberian health education tentang pencegahan infeksi nosokomial, hampir seluruhnya adalah baik, yaitu sebanyak 25 responden $(83 \%)$.

3. Ada pengaruh pemberian health education tentang pencegahan infeksi nosokomial terhadap pengetahuan keluarga pasien di Ruang Alamanda RSUD Nganjuk. Hal ini dibuktikan dari hasil uji Wilcoxondengan $\alpha=0,05$ menunjukkan bahwa $p$-value $=0,020(p$ value $\leq \alpha$ ) sehingga Ha diterima.

\section{DAFTAR PUSTAKA}

Arikunto, S. 2010. Prosedur Penelitian Suatu Pendekatan Praktik. Jakarta: Rineka Cipta.

Darmadi. 2008. Infeksi Nosokomial: Problematika dan Pengendaliannya. Jakarta: Salemba Medika.

Fajriyah, N.N. 2015.Pengetahuan Mencuci Tangan Penunggu Pasien Menggunakan Lotion Antiseptic. Jurnal: The 2nd University Research Coloquium 2015. ISSN 24079189.Hal.557-562.

Marwoto, Bady Agus. 2007. Analisis Kinerja Perawat dalam Pengendalian Infeksi Nosokomial di Ruang IRNA 1 RSUP. Dr. Sardjito, Yogyakarta. Sumber: http://www.docstoc.com/docs/389060 36.co.i. Diunduh: Tanggal 24 Agustus 2017. Jam 15.45 WIB.

Mubarak, W. I. 2007.Promosi Kesehatan Sebuah Pengantar Proses Belajar Mangajar dalam Pendidikan. Yogyakarta: Graha Ilmu.

Mubarak, W.I. dan Chayatin N. 2009.Ilmu Kesehatan Masyarakat Teori dan Aplikasi. Jakarta: Salemba Medika.

Notoatmodjo, S. 2011. Ilmu Perilaku Kesehatan. Jakarta: Rineka Cipta.

Nugrohoi, C. V. 2014. Pengaruh Pemberian Materi Kesehatan Reproduksi Melalui Grup Facebook Terhadap Pengetahuan Remaja. Jurnal Promkes. FKM Unair Surabaya.

Nursalam. 2016. Konsep dan Penerapan Metodologi Penelitian Ilmu Keperwatan. Jakarta: Salemba Medika.

Tim Penyusun Komite PPI. 2017. Laporan PPI. RSUD Nganjuk. 